\title{
LONG-RUN AND SHORT-RUN RELATIONSHIPS BETWEEN EDUCATION AND ECONOMIC GROWTH: THE MALAYSIAN EXPERIENCE
}

\author{
ISHAK YUSSOF \\ ATIF AWAD ABDILLAH \\ ZULKIFLY OSMAN \\ Faculty of Economic and Business \\ Universiti Kebangsaan Malaysia
}

\begin{abstract}
This paper investigates the long and short-run relationships between human capital, measured in terms of average years of schooling for people aged 15 years and older, and economic growth in Malaysia between 1970 and 2009. The data was collected from various sources, including the World Bank database, the International Labour Organization (ILO) and scholarly texts. The Auto Regressive Distributed Lag (ARDL) test was utilized to examine the relationships between education and economic growth. The results of the co-integration test revealed that economic growth was absolutely exogenous and the remaining variables were endogenous in Malaysia. This finding suggests that the status of these variables depend on the level of economic growth, while the opposite is not true. The most interesting results were that the long-run forcing variables for human capital accumulation were capital stock, employment and economic growth. However, the causality test revealed that economic growth, employment and capital stock, not only affects human capital in the short-run, but in the long-run as well. The causality tests performed detected two-way relationships between human capital and capital stock, and employment separately in the long run. Although economic growth is exogenous, Malaysia should still continue to invest in its human capital accumulation since it could attract more investments and subsequently create employment opportunities within the economy.
\end{abstract}

Keywords: Education levels, education development, income, economic growth.

\section{Introduction}

Although controversy exists concerning the best means to measure the relative contribution of education to economic growth, agreement exists regarding the critical role of education to economic growth. 
Schultz (1961) claims that economic growth is not determined by the quantity of labour or physical capital invested, but is determined by the quality of the labour. Education plays a critical role in determining the quality of such labour. Using human capital theory, Schultz (1961) explains that economic growth is assumed to be related to the quality of the labour force and, hence, the level of educational investment. According to the World Bank (1994, 124), there is sufficient evidence that higher enrollments and rapid responses of the education system to the changing labour markets explains a significant part of the high growth rates of high-performing East Asian economies in recent decades. Nevertheless, it is still not clear that increasing investment in education, particularly higher level education, will foster rapid economic growth.

Economies deteriorated rapidly during the 1973 oil crisis and expectations for education turned pessimistic due to the escalating unemployment phenomena across countries.This has led to the development of the view that a strong governmental policy is crucial to create the demand for labour and subsequently the economic growth of the countries affected by the crisis. According to this perspective, irrespective of how much high quality labour is supplied to a market, the economy will continue to decline if there is no demand for labour (OECD, 1997). However, this view fails to recognise that investment in human capital (i.e. education and training) forms a foundation for the realization of economic and social policies introduced by the government. While it is recognized that educational investment is necessary, the critical question concerns how much educational investment is required in order to sustain economic growth. On the other hand, over-investment in the educational system will undermine other sectors of the economy by denying them resources.

Although it is reasonable to regard education as a fundamental source of economic growth, spending on education is also facilitated by the growth of national income (Jones, 1992). It is a complex relationship. The contribution of education to growth is presumed to occur through its ability to increase the productivity of an existing labour force. Although there is still no strong evidence that more schooling does raise industrial-worker productivity, it is a plausible hypothesis. Furthermore, fundamental beliefs in the socio-economic benefits of education have also led to its rapid expansion in many developing countries (Teichler, 2000). 
This paper examines the long-and short-run relationships between Malaysia's economic growth and educational development over the last 40 years. The main objective is to offer a more comprehensive analysis and review of the contribution of education to economic growth in Malaysia using time series data. Previous studies investigating the issue either employed cross-section data or timeseries data relating to relatively shorter periods (Hui-Boon Tan, MeiFoong \& Zaleha, 2006; Ishak \& Zainizam, 2009; Rao \& Rohana, 2009; Idris \& Rahmah, 2010). Such approaches are less efficient in explaining the dynamic aspect of the relationships. Moreover, the present study focuses on the contribution of different levels of education to growth which may be useful among policy makers in regards to the efficient allocation of resources within the educational system. This paper is organised into six sections. After the introduction, we offer a brief review on education development and economic growth in Malaysia. Section three examines relevant literature which contributed to the debate, followed by an explanation of the methodological framework in Section four. Section five presents the empirical analysis and, finally, policy implications are considered in the final section.

\section{Education Development and Economic Growth in Malaysia}

Since independence, Malaysia has experienced several periods of rapid economic growth and has been recognised as a fast-growing economy alongside other successful East Asian economies. As economic development has proceeded over the last fifty years, significant changes have also occurred in the national economic structure. The economy, which was initially heavily reliant upon agriculture activities, has now been transformed into a modern and industrial-based economy. For example, the share of the primary sector production to GDP declined from 49.8 per cent in 1957 to 14.9 per cent in 2005, further decreasing to less than 12 per cent in 2010. In contrast, the share of the secondary sector, primarily composed of manufacturing industries, rose sharply from 9.2 per cent in 1957 to more than 34 per cent in 2010. A similar shift also occurred in the services sector and it is expected that this sector shall be the engine of growth for the economy in the future (Malaysia, 2010).

Indeed, economic progress and transformation have played important roles in shaping the educational system, as well as the employment structure of the country. Figure 1 shows that Malaysian real per capita 
GDP has increased from RM4,352 in 1970 to more than RM19,000 in 2008-2009. Accordingly, Malaysia's education system has changed to help meet these new economic changes and challenges. Generally, each student is required to complete six years of primary education. In 1961, only 77.4 per cent of primary-school-age children were in school. However, by 1990, at least 99 per cent of the primary-schoolage population had already enrolled at the primary school level.

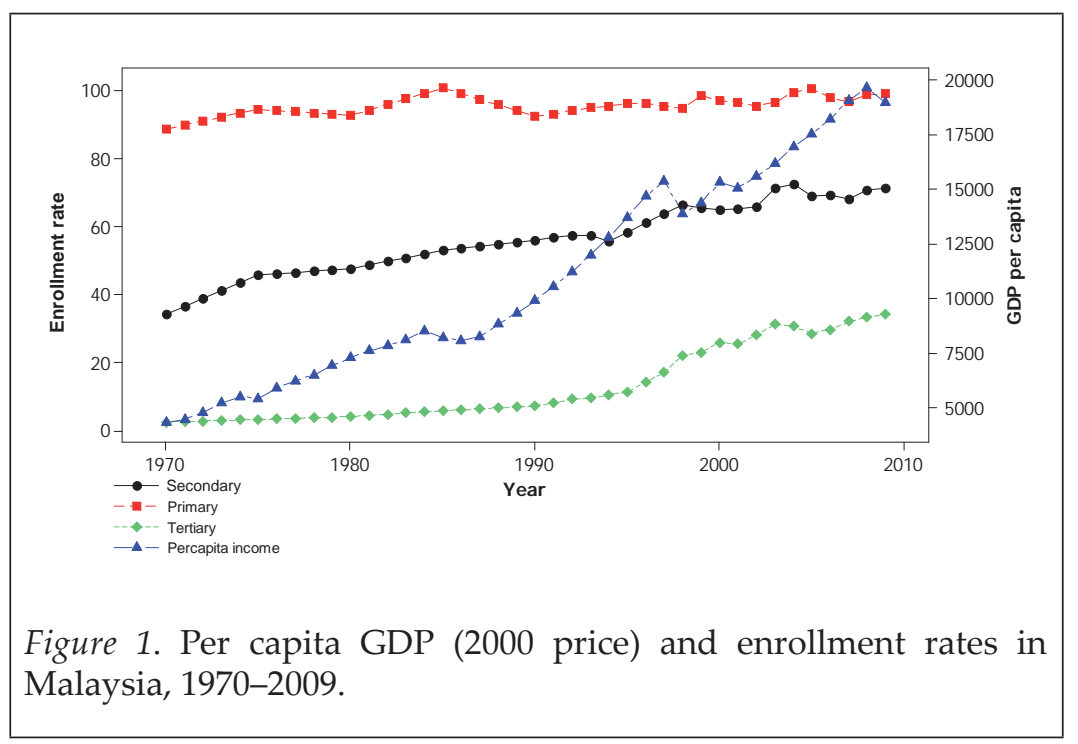

Secondary education has become more comprehensive since 1978 . Lower secondary school enrollments grew from 13.7 per cent of the eligible age group in 1961 to 37 per cent in 1980, rising to 49 per cent by 1994. In 1999, the secondary school enrollment rate stood at 79 per cent, illustrating the progress that the government has made in providing lower secondary education. College or university level enrollment rates have also grown rapidly. While enrollments in tertiary education stood only at 1.3 per cent of the school-age population in 1970, the rate rose to almost 35 per cent by 2010 .

Malaysia has made an exceptional effort to develop its educational system during the past four decades. The government has always accorded high priority to education as is reflected in the extensive coverage in all of the previous five-year development plans. On average, education expenditures accounted for more than 25 per cent of the total government expenditures, or 6.2 per cent of gross domestic product (GDP). This ratio is relatively high when compared 
with other developed nations and newly industrialising economies in the Asia region, with an average of only 3-4 per cent of the GDP (UNESCO, 2008). Subsequently, the Malaysian educational system is likely to be superior since it receives considerable investment from the government (World Bank, 2007). For example, Table 1 shows that the pupil/teacher ratio in the primary school in Malaysia is comparable with those in developed nations. As a developing nation, Malaysia's enrollment ratios by level of schooling reflected in Table 1 are also considered relatively high.

Table 1

International Comparison of Basic Educational Indicators

\begin{tabular}{|c|c|c|c|c|c|c|}
\hline \multirow[b]{2}{*}{ Country } & \multicolumn{2}{|c|}{$\begin{array}{l}\text { Public expenditure } \\
\text { on education (2004) }\end{array}$} & \multirow{2}{*}{$\begin{array}{c}\text { Pupil-teacher } \\
\text { ratio (Primary) } \\
\quad(2006)\end{array}$} & \multicolumn{3}{|c|}{$\frac{\text { Net enrollment ratio, } \%}{(2006)}$} \\
\hline & $\begin{array}{c}\text { As } \\
\% \text { of } \\
\text { GDP }\end{array}$ & $\begin{array}{c}\text { As } \% \\
\text { of total } \\
\text { government } \\
\text { expenditure }\end{array}$ & & Primary & Secondary & Tertiary \\
\hline$\overline{\mathrm{US}}$ & 5.3 & 13.7 & 14 & 92 & 88 & 82 \\
\hline UK & 5.6 & 12.5 & 18 & 98 & 92 & 59 \\
\hline Malaysia & 6.2 & 25.2 & 17 & 95 & 65 & $28^{\mathrm{b}}$ \\
\hline Japan & 3.5 & 9.2 & 19 & 100 & 99 & 57 \\
\hline South Korea & 4.6 & 16.5 & 28 & 98 & 94 & 91 \\
\hline China & 1.9 & 13.0 & 18 & - & - & 22 \\
\hline
\end{tabular}

Source. Data adapted from UNESCO website - http://stats.uis.unesco.org/unesco/ Notes. $\mathrm{a}=$ value for gross enrollment ratio; $\mathrm{b}$ = figure for 2002.

Under recent economic initiatives (New Economic Model, Economic Transformation Plan), Malaysia aspires to emerge as a higher-income economy with per capita income increasing from US\$6,700 to at least US $\$ 15,000$. Therefore, it is crucial to ensure that further educational investment and expansion, particularly at the higher levels (post-secondary and tertiary education), is efficient and, more importantly, corresponds with current and future economic growth (Ahmad Fauzi, Zakariah \& Raja Zarina, 2011).

\section{Literature Review}

The relationship between education and economic growth has been one of the principal focuses in research concerning the economics of education. Although, many studies generally agree that education 
contributes to economic growth, it is also argued that education requires a substantial amount of financial resources, particularly in regards to higher leveleducation. Constraints on government resources necessitate the reconsideration of priorities in investment based upon the appropriate level of education required to support economic growth. Previous studies have resulted in countless attempts to apply various theoretical models to investigate such issues, including Solow (1957); Schultz (1960); Mincer (1974); Romer (1986); Lucas (1988); Barro (1991) and Barro and Lee (1993). Hence, Johnes (2006) argues that the empirical evidence is mixed and puzzling. Furthermore, issues regarding different schooling levels which may have dissimilar effects on growth have not been adequately addressed adequately (World Bank, 1996; Psacharopoulos, 1996; Krueger \& Lindahl, 2001).

Using the rates of return method, Schultz (1961) determines that the contribution of schooling to the US economy occurs in the form of an increase in students' future earnings and, subsequently, the productivity capacity of labour. Although heavily criticised, the study establishes the existence of a relationship between education and economic growth. Later studies conducted by Denison (1962; 1967) utilize the growth-accounting model (also known as the residual approach) to explain education's contribution to economic growth and include adjusted labour inputs to reflect changes in the age, sex composition, working hours and levels of education. In earlier findings, Denison (1962) estimates that 23 per cent of the growth in the United States between 1930 and 1960 was due to the increased level of education of the workforce. However, in another comparative study between the countries in North America and Europe, Denison finds a wide variation in the educational contribution to economic growth, ranging from 2 per cent, in countries such as Germany, to 25 per cent, in countries such as Canada (Denison, 1967). Both studies demonstrate that investment in human capital, particularly through education, has made a significant contribution to economic growth.

While a study conducted Benhabib and Spiegel (1994) show that changes in education provide no significant coefficients, sometimes even negative coefficients, regarding growth, Jorgenson, Stiroh, Gordon and Sichel (2000) continued to demonstrate that education contributes positively to economic growth. According to Dahlin (2005), investment in education is very advantageous to the society, at both the micro level and the macro level, as it affects the system both directly and indirectly. At the individual level, Heckman and Klenow (1997) report that the direct and indirect effects of education occur in the form of wage increases and arriving externalities. 
A series of studies on the returns to investment in education undertaken by George Psacharopoulos have updated the understanding of the contribution of education to economic growth (see Psacharopoulos, $1973 ; 1981 ; 1985 ; 1989 ; 1994)$. The contributions of education to economic growth are arguably larger than previously thought, considering all the indirect effects of education on other social welfare indicators (Psacharopoulos, 1984). Using data from three household surveys in Mexico in 1984, 1989 and 1992, Psacharopoulos found that returns to education remain high, even after a significant expansion of the educational system (Psacharopoulos et al., 1996). These results indicate that educational expansion has a significant correlation with economic growth, though the directions of causation may be debated.

Irrespective of the positive findings, the debate on the contribution of education to economic growth continues. Islam (1995) and Caselli et al. (1996) report that education variables appear with the wrong sign in growth regressions. Pritchett (2001) finds that changes in schooling have no impact on economic growth. Temple (2001) argues that in large samples of countries, the relationship between education and economic growth is still inconclusive. Methodological issues and systematic failures regarding regression had led some researchers to question the quality of education data. Surprisingly, Hanushek and Kimko (2000) find that the quality of labour has a strong causal relationship with economic growth, but is not related to investment in formal schooling. In this case, education helps in accumulating sufficient human capital to facilitate the adoption of new technology, as well as promote innovations among workers, which contributes to the growth process.

In another study, Krueger and Lindahl (2001) argue that measurement error in the education variables, (i.e. years of schooling) is a major cause of the apparent lack of a significant relationship between education and economic growth. The study divides countries into three groups based on education levels and discovers a positive link between education and growth only in countries with the lowest level of education. The quadratic relationship between economic growth and the years of schooling is explored and reveals that education contributes positively to growth in countries with low levels of education, whereas education appears to depress economic growth in countries with high levels of education. Soto (2002) discusses the puzzling lack of relationship between education and economic growth in past studies and argues that the controversial results may stem from the definition of the education variables; the existence of 
co-linearity between physical and human capital stocks; or the failure to tackle measurement errors as well as end ogeneity problems. After dealing with these problems sufficiently, the study shows positive results.

The fact that different levels of schooling may have dissimilar effects on growth has not been addressed adequately and results are inconclusive. In several extensive comparative studies on returns to education in developed and developing countries, Psacharopoulos (1973; 1981; 1985 and 1994) finds that both private and social returns are relatively high at the primary and secondary levels. Amongst Asian countries, the social rates of return are estimated at 27 per cent for the primary level, 15 per cent for the secondary level, and 13 per cent for higher level education (Psacharopoulos, 1985). These studies tentatively suggest that developing countries should prioritise their investment in primary and secondary education, rather than in tertiary education, due to the returns incurred.

However, the findings of Lau, Jamison and Lou (1991) differ following an examination of the impact of primary and secondary schooling on economic growth in five regions. The results show that primary schooling has a negative effect on growth in Africa and the Middle East; effects seem to be insignificant in South Asia and Latin America; and effects are positive and significant in East Asia.

In a more recent study, Petrakis and Stamatakis (2002) show that primary and secondary education is crucial for economic growth in less developed countries in comparison to more developed economies. Papageorgiou (2003) finds that primary education is more important in final goods production, whereas post-primary education is essentially related to technology adoption and innovation. While Gyimah-Brempong et al. (2006) find that all levels of education have positive effects on the growth rate of per capita income in African counties. Using time-series data, Self and Grabowski (2004) conducted a Granger causality procedure to investigate whether education had a causal impact on economic growth in India. Their analysis demonstrated that primary education had a strong impact on growth, with somewhat limited effects at the secondary level.

Additionally, very few studies investigate the relationship between education and growth in the long-run. For example, Sari and Soytas (2006) examine the relationship between real income and enrollments in primary, secondary, high schools and higher education in Turkey 
for the period between 1937 and 1996 in a multivariate framework and discover a long-run co-integrating relationship between real income and educational variables; and bi-directional Granger causality between real income and educational variables in both the long-run and the short-run.

Similarly, there are also limited studies which examine the relationship between education and economic growth within a causality framework and report mixed results. De Meulemeester and Rochat (1995) reveal a unidirectional short-run Granger causality running from higher education enrollments to economic growth for Sweden, the United Kingdom, Japan, and France and neutrality between higher education enrollments and economic growth for Australia and Italy. Asteriou and Agiomirgianakis (2001) find a bidirectional causality between economic growth and primary and secondary school enrollments for the United States and Greece. Self and Grabowski (2003) find a causality relationship between primary education and economic growth for Japan in both the pre-war and post-war periods; evidence of a Granger causality running from secondary and tertiary education to economic growth for the postwar period; and feedback from income to all levels of education in both periods. In a different study, Self and Grabowski (2004) find a uni-directional Granger causality running from primary education enrollments to income in India. Therefore, further examination on this issue may shed some light and contribute to a better understanding of the relationship between education development and economic growth.

\section{Method and Model Specifications}

In this section, the methodology will be briefly discussed. As mentioned previously, the overall objective of this study is to investigate the long-and short-run relationships between the variables, as well as the direction of the causality relationship between the same variables in the long-and short-run. Thus, the study estimates the parameters by the log-linearized Cobb-Douglas production function. The basic production function takes the following form:

$$
Y=A K^{a} L^{\beta}
$$

Based on the endogenous economic growth theory, namely Lucas (1988), the human capital variable is entered to the above function as additional inputs. The choice of this type of production function follows international literature on neoclassical growth models 
(Abbas, 2008; Adawo, 2011; Uwatt, 2002). The log-linearized CobbDouglas production function takes the following form:

$$
\log \mathrm{Y}_{\mathrm{t}}=\mathrm{a}+\propto \log \mathrm{K}_{\mathrm{t}}+\beta \log \mathrm{L}_{\mathrm{t}}+\gamma \log \mathrm{H}_{\mathrm{t}}+\epsilon_{\mathrm{t}}
$$

Where $\mathrm{Y}$ represents the real GDP(2000 prices), $\mathrm{K}$ represents the real physical capital (2000 prices), L represents total employment, $\mathrm{H}$ represents the human capital (average years of schooling), $\in$ represents the error term and $t$ represents time. This specification implies that the econometric estimations do not impose any restrictions on the value of the parameters (the elasticity's product-factor) in trying to get the answer to our problem from the data. Thus, we do not impose the existence of a constant return to scale as a condition for the estimation of the model. This form of estimation eliminates restrictions imposed in the returns to scale for the set of inputs considered, while allowing for the determination of the sign of each of the parameters of the function. The economic theory imposes positive values for each of the elasticity product-factor, but the empirical analysis can disclose a distinctive result, specific to the economy being analyzed, that will be tested.

This study adopts considerations of existing literature in selecting the relevant proxies for the input variables. The study used total employment as an indicator for labour and real capital stock (derived from real gross fixed capital formulation) as an indicator for physical capital (Abbas, 2001; Adawo, 2011; Barro, 1991; and Ndiyo, 2002). The study employed the average years of schooling for the population aged 15 and above in regards to human capital. Data on real GDPs, real fixed gross capital formulation and total labour force were obtained from the World Bank database. Data regarding the average years of schooling was collected from Barro and Lee (2010). In fact, the most widely used estimates of the human capital stock for various countries of the world are those of Barro and Lee (2010; 2001 and 1993). Missing data for some variables was estimated using straightline interpolation or extrapolation methods.

\section{Variables Definition and Measurement}

\section{(a) Real GDP (Y)}

Real GDP is GDP at 2000 market prices less indirect taxes net of subsidies. Here, real per capita GDP is used as an indicator of the economic growth of a country. 


\section{(b) Real Capital Stock (K)}

The total physical capital existing in an economy at any moment of time is referred to as capital stock. For this study, data on real capital stock is derived from real capital formation at the 2000 constant basic price using this formula $K_{t=} \sum_{j=0}(1-d)^{t-\jmath}\left(\frac{I_{j}}{P_{j}}\right)$. Where $\mathrm{K}_{\mathrm{t}}$ is the capital stock at period T, $\mathrm{d}$ is the rate or aepreciation, $\mathrm{I}_{\mathrm{i}}$ is the total investment at period ${ }_{j}$ and $P_{j}$ is the price level at period ${ }_{j} . I_{j} / P_{j}$ is the real value of the investment, in this case it is replaced by the value of real fixed capital formation. Sudan does not provide data on physical capital stock, providing data on capital formation (investment) every year instead. For the purposes of this study, we compute real capital stock from real capital formation using the above formula. In the absence of specific micro surveys or information regarding the various tax legislations, the depreciation rate has been set at 10 per cent, in line with other studies, such as Bisat et al. (1997) or Abu-Qarn and Abu-Bader (2007).

\section{(c) Employment (L)}

The term 'employed persons' was defined in the Resolution concerning statistics of the economically active population, employment, unemployment and underemployment, adopted by the Thirteenth International Conference of Labour Statisticians (Geneva, 1982), as:

...all persons above a specific age who during a specified brief period, either one week or one day, were in the following categories: (a1) "paid employment" "at work": persons who during the reference period performed some work for wage or salary, in cash or in kind; (a2) "with a job but not at work": persons who, having already worked in their present job, were temporarily not at work during the reference period and had a formal attachment to their job. This formal job attachment should be determined in the light of national circumstances, according to one or more of the following criteria: (i) the continued receipt of wage or salary, (ii) an assurance of return to work following the end of the contingency, or an agreement as to the date of return, (iii) the elapsed duration of absence from the job which, wherever relevant, may be that duration for which workers can receive compensation benefits without obligations to accept other jobs. (b) "self-employment": (b1) "at work": persons who during the reference period performed 
some work for profit or family gain, in cash or in kind; (b2) "with an enterprise but not at work": persons with an enterprise, which may be a business enterprise, a farm or a service undertaking, who were temporarily not at work during the reference period for any specific reason.

\section{(d) Average years of schooling $(\mathrm{H})$}

Average years of schooling for adults are the years of formal schooling received, on average, by adults over the age of $15 .{ }^{1}$

\section{Estimation Procedures}

\section{(a) Stationary test}

The following discussion outlines the basic features of unit root tests. By necessity, the discussion will be brief ${ }^{2}$. Consider a simple first auto regressive $\mathrm{AR}(1)$ process:

$$
y_{t}=\rho y_{t-1}+\tilde{x}_{t} \sigma+\epsilon_{t}
$$

Where $x_{t}$ are optional exogenous regressors which may consist of constant or a constant and trend, $\rho$ and $\sigma$ are parameters to be estimated and $\in$ is assumed to be white noise. If $[\rho] \geq 1, y$ is a non-stationary series and the variance of $y$ increases with time and approaches infinity. If $[\rho] \leq 1, y$ is a stationary series. Thus, the hypothesis of stationarity can be evaluated by testing whether the absolute value of $y$ is strictly less than one. Most of the unit root tests test the null hypothesis $H_{0}: \rho=1$ against the one-sided alternative $H_{1}: \rho<1$. In some cases, the null is tested against a point alternative. In contrast, the KPSS Lagrange Multiplier test evaluates the null of $H_{0}:<\rho 1$ gainst the alternative $H_{1}: \rho=1$.

Several unit root tests exist to determine whether the series is stationery. In order to proceed to the co-integration analysis, one must establish that the variables possess the same order of integration. The process examining the time-series characteristics of the variables selected overcomes the problems of spurious correlation that frequently occur with non-stationary time-series and generate long-run equilibrium relationships concurrently. The data series were tested for stationary using the Augmented Dickey Fuller (ADF) and the Philip-Perron (PP) test as the starting point to assess the order of integration. The ADF test and the PP test are widely used methods of investigating the presence of a unit root in single time series. Unfortunately, in finite 
sampling, these tests suffer from limited power against near unit root alternatives (Maddala \& Kim, 1998). DeJong et al. (1992), for example, report evidence that the Dickey-Fuller test has low power against autoregressive alternatives with near unit roots.

In this study, we use the KPSS test (Kwiatkowski et al., 1992) as a third unit root test to avoid the problem of limited power against near unit root alternatives associated with $\mathrm{ADF}$ and PP tests; to resolve the contradictory results which may appear when as a result of the use of just the ADF and the PP tests; and to confirm and complement the results obtained by the other two tests. In fact, the main difference between the KPSS test; and both the ADF and PP tests is the null hypothesis. Whereas the ADF test and the PP test are tests for unit roots (or non-stationary), the null hypothesis of the KPSS test is the absence of a unit root (or stationary of the series). Kwiatkowski et al. (1992) conclude that by testing both the unit root hypothesis and the stationary hypothesis, one can distinguish the series that appear to be stationary; the series that appear to have a unit root; and the series for which the data (or the tests) are not sufficiently informative to be sure whether they are stationary or integrated.

\section{(b) ARDL model specification}

To empirically analyse the long-run relationships and dynamic interactions among the variables of interest, the model has been estimated by using the bounds testing (or auto-regressive distributed lag (ARDL)) co-integration procedure, developed by Pesaran et al. (1999). The procedure is adopted for the following three reasons. Firstly, the bounds test procedure is simple. As opposed to other multivariate co-integration techniques, such as Johansen and Juselius (1990), it allows the co-integration relationship to be estimated by OLS once the lag order of the model is identified. Secondly, the bounds testing procedure does not require the pre-testing of the variables included in the model for unit roots unlike other techniques, such as the Johansen approach. It is applicable irrespective of whether the regressors in the model are purely $\mathrm{I}(0)$, purely $\mathrm{I}(1)$ or mutually co-integrated. Thirdly, the test is relatively more efficient in small or finite sample data sizes as is the case in this study. The procedure will however crash in the presence of $\mathrm{I}(2)$ series.

Following Pesaran et al. (1999), as summarized in Choong et al. (2005), we apply the bounds test procedure by modelling the longrun Equation (2) as a general vector autoregressive (VAR) model of order $\mathrm{p}$, inz: 


$$
z_{t}=c_{0}+\beta_{t}+\sum_{i=1}^{p} \emptyset_{i} z_{t-i}+\epsilon_{t}
$$

With $t$ denoting time $1,2,3 \ldots$ and $\mathrm{c}_{0}$ representing $\mathrm{a}(\mathrm{k}+1)$ vector of intercepts (drift) and $\beta$ denoting a $(\mathrm{k}+1)$ vector of trend coefficients. Pesaran et al. (1999) further derived the following vector equilibrium correction model (VECM) corresponding to Equation (3):

$$
\Delta z_{t}=c_{0}+\beta_{t}+\Pi z_{t-1}+\sum_{i=1}^{p} \Gamma_{i} \Delta z_{t-i}+\epsilon_{t}
$$

Where the $(\mathrm{k}+1) \times(\mathrm{k}+1)$ matrices $\Pi=\mathrm{I}_{\mathrm{k}+1}+\sum_{\mathrm{i}=1}^{\mathrm{p}} \varphi_{\mathrm{i}}$ and $\Gamma_{\mathrm{i}}=-\sum_{\mathrm{j}=\mathrm{i}+1}^{\mathrm{p}}$ $\varphi_{\mathrm{j}}, \mathrm{j}=1,2, \ldots \mathrm{p}-1$ contain the long-run multipliers and the shortrun dynamic coefficients of the VECM. $z_{t}$ is the vector of variables $y_{t}$ and $x_{t}$ respectively. $y_{t}$ is an $I(1)$ dependent variable defined as $\log y_{t}$ and $x=\{\mathrm{L} \mathrm{K} \mathrm{H}\}$ is a vector matrix of 'forcing' $I(0)$ and $I(1)$ regressors as already defined with a multivariate identically and independently distributed zero mean error vector $\varepsilon_{\mathrm{t}}=\left(\varepsilon_{1 \mathrm{t}} \varepsilon_{2 \mathrm{t}}\right)$ and a homoskedastic process. Further assuming that a unique long-run relationship exists among the variables, the conditional VECM (4) now becomes:

$$
\begin{aligned}
& \Delta \mathrm{Y}_{\mathrm{t}}=\mathrm{c}_{\mathrm{y} 0}+\beta_{\mathrm{t}}+\delta_{\mathrm{yy}} \mathrm{Y}_{\mathrm{t}-1}+\delta_{\mathrm{xx}} X_{\mathrm{t}-1}+ \\
& \sum_{\mathrm{i}=1}^{\mathrm{p}-1} \gamma_{\mathrm{i}} \Delta \mathrm{Y}_{\mathrm{t}-\mathrm{i}}+\sum_{\mathrm{i}=0}^{\mathrm{p}-1} \vartheta_{\mathrm{i}} \Delta \mathrm{X}_{\mathrm{t}-1}+\epsilon_{\mathrm{yt}}
\end{aligned}
$$

On the basis of equation (4), the conditional VECM of interest can be specified as:

$$
\begin{aligned}
& \ln \mathrm{Y}_{\mathrm{t}}=c_{0}+\delta_{1} \mathrm{lY}_{\mathrm{t}-1}+\delta_{2} \mathrm{lK}_{\mathrm{t}-1}+\delta_{3} \mathrm{lL}_{\mathrm{t}-1}+\delta_{4} \mathrm{lH}_{\mathrm{t}-1}+ \\
& \sum_{\mathrm{i}=1} \varphi_{\mathrm{i}} \Delta \mathrm{l} \mathrm{Y}_{\mathrm{t}-\mathrm{i}}+\sum_{\mathrm{j}=1} \phi_{\mathrm{j}} \Delta \mathrm{l} \mathrm{K}_{\mathrm{t}-\mathrm{j}}+\sum_{\mathrm{n}=1}^{\mathrm{q}} \Psi_{\mathrm{n}} \Delta \mathrm{lL} \mathrm{L}_{\mathrm{n}-1}+\sum_{\mathrm{s}=1}^{\mathrm{q}} \Omega_{\mathrm{s}} \Delta \mathrm{lH}_{\mathrm{s}-1}+\varepsilon_{\mathrm{t}}
\end{aligned}
$$

Where $\delta_{\mathrm{i}}$ are the long-run multipliers, cois the drift and $\varepsilon_{\mathrm{t}}$ are white noise errors.

\section{(c) Bounds testing procedure}

The first step in the ARDL bounds testing approach is to estimate Equation (9) through the ordinary least squares (OLS) method in order to test for the existence of a long-run relationship among the variables by conducting an F-test with the following hypotheses:

$$
\begin{aligned}
& H_{0}=\delta_{1}=\delta_{2}=\delta_{3}=\delta_{4}=0 \\
& H_{1} \neq \delta_{1} \neq \delta_{2} \neq \delta_{3} \neq \delta_{4} \neq 0
\end{aligned}
$$


We denote the test, which normalizes on $\mathrm{Y}$, by FY(Y/K, L,H). Two asymptotic critical value bounds provide a test for co-integration when the independent variables are $I(d)$ (where $0<d<1)$ : a lower value assuming the regressors are $I(0)$ and an upper value assuming purely I(1) regressors. If the F-statistic is above the upper critical value, the null hypothesis of no long-run relationship can be rejected irrespective of the orders of integration for the time series. Conversely, if the test statistic falls below the lower critical value the null hypothesis cannot be rejected. Finally, if the statistic falls between the lower and upper critical values, the result is inconclusive. The approximate critical values for the F test were obtained from Pesaran et al. (1997). In the second step, once co-integration is established the conditional ARDL $\left(\mathrm{p}_{1}, \mathrm{q}_{1}, \mathrm{q}_{2}, \mathrm{q}_{3}\right)$ long-run model for $\mathrm{Y}_{\mathrm{t}}$ can be estimated as:

$$
\begin{aligned}
& \ln \mathrm{Y}_{\mathrm{t}}=\mathrm{c}_{\circ}+\sum_{\mathrm{i}=1}^{\mathrm{p}} \delta_{1} \ln \mathrm{Y}_{\mathrm{t}-\mathrm{i}}+\sum_{\mathrm{i}=0}^{\mathrm{q} 1} \delta_{2} \ln \mathrm{K}_{\mathrm{t}-\mathrm{i}}+ \\
& \sum_{\mathrm{i}=0}^{\mathrm{q} 2} \delta_{3} \ln \mathrm{L}_{\mathrm{t}-\mathrm{i}}+\sum_{\mathrm{i}=0}^{\mathrm{q} 3} \delta_{4} \ln \mathrm{H}_{\mathrm{t}-\mathrm{i}}+\epsilon_{\mathrm{t}}
\end{aligned}
$$

This involves selecting the orders of the ARDL $\left(p, q_{1}, q_{2}, q_{3}\right)$ model in the three variables $(K, L, H)$ using the Akaike Information criterion (AIC) or the Schwarz Bayesian criterion (SBC). In the third and final step, we obtain the short-run dynamic parameters by estimating an error correction model associated with the long-run estimates. This is specified as follows:

$$
\begin{aligned}
& \Delta \ln Y_{\mathrm{t}}=\mu+\sum_{\mathrm{i}=1}^{\mathrm{p}} \varphi_{\mathrm{i}} \Delta \ln \mathrm{Y}_{\mathrm{t}-\mathrm{i}}+\sum_{\mathrm{j}=1}^{\mathrm{q}} \emptyset_{\mathrm{j}} \Delta \ln \mathrm{K}_{\mathrm{t}-\mathrm{j}}+ \\
& \sum_{\mathrm{n}=1}^{\mathrm{q}} \Psi_{\mathrm{n}} \Delta \ln \mathrm{L}_{\mathrm{t}-\mathrm{n}}+\sum_{\mathrm{s}=1}^{\mathrm{q}} \Omega_{\mathrm{s}} \Delta \ln _{\mathrm{t}-\mathrm{s}}+\theta \mathrm{ECM}_{\mathrm{t}-1}+\epsilon_{\mathrm{t}}
\end{aligned}
$$

Here $\varphi, \phi, \Omega$ and $\Psi$ are the short-run dynamic coefficients of the model's convergence to equilibrium and $\theta$ is the speed of adjustment.

\section{Results and Discussion}

\section{(a) Unit Root Test}

Before proceeding with the ARDL bounds test, the stationarity status of all variables is tested to determine their order of integration. This is to ensure that the variables are not I(2) stationary so as to avoid spurious results. According to Ouattara (2004), variables in the presence of $\mathrm{I}(2)$ used to compute F statistics provided by Pesaran (2001) are not valid because the bounds test is based on the assumption that the variables 
are $\mathrm{I}(0)$ or I(1). Subsequently, it is therefore necessary to instigate unit root tests in the ARDL procedure to ensure that none of the variables are integrated of order 2 or beyond. Data series are tested for stationarity by using the ADF,PP and KPSS tests as the starting point to assess the order of integration. The results of the tests at the level as well as the first level are explained in Table 2 and Table 3.

Table 2

Unit Root Test at Level

\begin{tabular}{|c|c|c|c|c|c|c|}
\hline \multirow{2}{*}{ Variables } & \multicolumn{3}{|c|}{ With trend } & \multicolumn{3}{|c|}{ Without trend } \\
\hline & ADF & PP & KPSS & ADF & PP & KPSS \\
\hline $\ln Y$ & $\begin{array}{l}-1.170714 \\
(0.9026)\end{array}$ & $\begin{array}{l}-1.316862 \\
(0.8699)\end{array}$ & 0.241620 & $\begin{array}{l}-1.822158 \\
(0.3646)\end{array}$ & $\begin{array}{l}-1.74467 \\
(0.4016\end{array}$ & 0.777295 \\
\hline $\ln K$ & $\begin{array}{l}-0.721019 \\
(0.9643)\end{array}$ & $\begin{array}{l}-0.860396 \\
(0.9505)\end{array}$ & 0.234724 & $\begin{array}{l}-1.459976 \\
(0.5430)\end{array}$ & $\begin{array}{l}-1.471024 \\
(0.5375)\end{array}$ & 0.7674202 \\
\hline $\ln L$ & $\begin{array}{l}-2.895581 \\
(0.1749)\end{array}$ & $\begin{array}{l}-3.340657 \\
(0.0747)\end{array}$ & 0.243466 & $\begin{array}{l}-5.583734 \\
(0.0000)^{* * *}\end{array}$ & $\begin{array}{l}-6.784998 \\
(0.0000)^{* * *}\end{array}$ & 0.767018 \\
\hline $\ln \mathrm{H}$ & $\begin{array}{l}-0.996666 \\
(0.9326)\end{array}$ & $\begin{array}{l}-0.667810 \\
(9686)\end{array}$ & 0.256258 & $\begin{array}{l}-2.315784 \\
(0.1724)\end{array}$ & $\begin{array}{l}-2.771049 \\
(0.0717)\end{array}$ & 0.762313 \\
\hline
\end{tabular}

Notes.

\# The prob value in parentheses ( ), and (***)indicate significant at $1 \%$ level.

\# Asymptotic critical values for KPSS test (without trend) 0.73900 (1\%), 0.460000 (5\%) and $34700(10 \%)$.

(with trend) $0.21600(1 \%), 0.14600(5 \%)$ and 0.11900 (10\%) from Kwiatkowski et al. (1992) Table (1).

The results of the unit root tests at the level suggest that all the variables have a unit root in their level except for variable $L$ (labour)in which the ADF and PP tests indicate I(0), while the KPSS test suggests it is not stationary at the level. Thus, to solve this contradiction, this variable is tested alongside the others at the first level, the results of which are presented in Table 3 below.

The result of the tests indicates that the null hypothesis (the series has a unit root for the ADF and the PP tests) at 1 per cent and 5 per cent significance level can be rejected at first level for the variables. Additionally, for the KPSS test, the null hypothesis (the series is stationarity) at 1 per cent and 5 per cent significance level can be rejected at first level for the variables. Therefore, it is possible to conclude that all the tests agree that the variables are integrated at the first level (I\{1\}).The results of the unit root test at the level, as 
well as the first difference order, affirmed the need to test for the cointegration among these variables. The second step tests whether a long-run relationship exists between the variables.

Table 3

Unit Root Test at First Level

\begin{tabular}{cllcccc}
\hline \multirow{2}{*}{ Variables With trend } & \multicolumn{3}{c}{ Without trend } \\
\cline { 2 - 6 } & \multicolumn{1}{c}{ ADF } & \multicolumn{1}{c}{ PP } & KPSS & ADF & \multicolumn{1}{c}{ PP } & KPSS \\
\hline $\ln \mathrm{Y}$ & -5.046076 & -5.063375 & $0.065696^{* * *}$ & -4.704082 & -4.654859 & $0.281635^{* * *}$ \\
& $(0.0011)^{* * *}$ & $(0.0011)^{* * *}$ & & $(0.0005)^{* * *}$ & $(0.0006)^{* * *}$ & \\
$\ln \mathrm{K}$ & $-7.356987^{* * * *}$ & $-7.236747^{* * *}$ & $0.096927^{* * *}-6.945919^{* * *}$ & $-6.919029^{* * *}$ & $0.249259^{* * *}$ \\
& $(0.0000)$ & $(0.0000)$ & $(0.0000)$ & $(0.0000)$ & \\
$\ln \mathrm{l}$ & $-7.352958^{* * *}$ & $-7.275588^{* * *}$ & $0.132582^{* * *}-5.242840^{* * *}$ & $-5.151799^{* * *}$ & $0.626044^{* * *}$ \\
& $(0.0000)$ & $(0.0000)$ & & $(0.0000)$ & $(0.0000)$ & \\
$\ln \mathrm{H}$ & $-4.000183^{* * *}$ & $-4.017994^{* *}$ & $0.049179^{* * *}-3.222177^{* *}$ & $-3.312552^{* *}$ & $0.453171^{* * *}$ \\
& $(0.0171)$ & $(0.0164)$ & & $(0.0263)$ & $(0.0212)$ & \\
\hline
\end{tabular}

Notes.

\#The prob value in parentheses ( );(**) and $\left(^{*}\right)$ indicate significant at $1 \%$ and $5 \%$ levels respectively.

\# Asymptotic critical values for KPSS test (without trend) 0.73900 (1\%), 0.460000 (5\%) and $34700(10 \%)$.

(with trend) $0.21600(1 \%), 0.14600(5 \%)$ and $0.11900(10 \%)$ from Kwiatkowski et al. (1992) Table (1).

\section{(b) Bounds tests for co-integration}

In the first step of the ARDL analysis, we tested for the presence of long-run relationships in Equation (4), using Equation (5). We used a general-to-specific modelling approach guided by the short data span and AIC respectively to select a maximum lag order of 2 for the conditional ARDL-VECM. Following the procedure in Pesaran et al. (1997), we first estimated an OLS regression for the first differences significance of the parameters of the lagged level variables when added to the first regression. According to Pesaran et al. (1997), "this OLS regression in first differences are of no direct interest" to the bounds co-integration test. The F-statistic checks the joint null hypothesis that the coefficients of the lagged level variables are zero (i.e., no long-run relationship exists between them). Table 4 reports the results of the calculated F-statistics when each variable is considered as a dependent variable (normalized) in the ARDLOLS regressions. 
IJMS 20 (1), 41-75 (2013)

Table 4

F-statistic of Co-integration Relationship

\begin{tabular}{ccccc}
\hline \multirow{2}{*}{ Lag length } & \multicolumn{4}{c}{ Function form } \\
\cline { 2 - 5 } & $\begin{array}{c}\ln \mathrm{Y}(\operatorname{lnK}, \operatorname{lnL}, \\
\ln \mathrm{H})\end{array}$ & $\begin{array}{c}\operatorname{lnK}(\operatorname{lnL}, \ln \mathrm{H}, \\
\ln \mathrm{Y})\end{array}$ & $\begin{array}{c}\operatorname{lnL}(\operatorname{lnK}, \ln \mathrm{H}, \\
\ln \mathrm{Y})\end{array}$ & $\begin{array}{c}\ln \mathrm{H}(\operatorname{lnK}, \operatorname{lnL}, \\
\ln \mathrm{Y})\end{array}$ \\
\hline 1 & 0.773149 & 0.77963 & $6.0656^{* * *}$ & 3.7334 \\
2 & 0.724821 & 1.2322 & $6.6815^{* * *}$ & $6.8562^{* * *}$ \\
3 & 0.96115 & $5.4945^{* *}$ & 0.99460 & $7.5130^{* * *}$ \\
4 & 1.1944 & $13.0913^{* * *}$ & 1.3559 & 3.7137 \\
5 & 1.8043 & 4.2321 & 2.6857 & 2.0201 \\
6 & 0.98715 & 2.1295 & 0.30874 & 2.9921 \\
\hline
\end{tabular}

Notes.

\# The upper limit of the critical value for the F-test (all I[1] variables) is 5.615 (1\%) and 4.378 (5\%) and Critical values obtained from Pesaran et al. (2001).

$\#\left({ }^{* * *}\right)$ and $(* *)$ denote significant at $1 \%$ and $5 \%$ respectively.

Table 4 clearly shows that there is a long-run relationship between the variables when capital stock, employment and human capital variables are considered as dependent variables; whilst an absence of such a relationship when economic growth is a dependent variable. These results indicate the exogeneity of the economic growth and, at the same time, endogeneity of the rest of the variables. Since evidence for the long-run relationship is detected where $\mathrm{K}$, L and $\mathrm{H}$ are considered as dependent variables, the next step is to estimate this relationship with its associated maximum lag length. Therefore, we estimated Equation (7) by considering $\mathrm{K}, \mathrm{L}$ and $\mathrm{H}$ as dependent variables and the result of these estimated equations is presented in Table 5.

Table 5

Long-run Coefficients

\begin{tabular}{lccc}
\hline \multirow{2}{*}{ Explanatory variables } & \multicolumn{3}{c}{ Dependent variable } \\
\cline { 2 - 4 } & \multicolumn{1}{c}{$\ln \mathrm{K}$} & \multicolumn{1}{c}{$\ln \mathrm{ln}$} \\
\hline Constant & $23.09(2.69)^{* *}$ & $0.74(0.43)$ & $-3.64(7.88)^{* * *}$ \\
$\ln \mathrm{Y}$ & $-0.63(0.75)$ & $0.31(3.24)^{* * *}$ & $-0.14(0.32)$ \\
$\ln \mathrm{N}$ & - & $-0.04(0.32)$ & $0.14(2.30)^{* *}$ \\
$\ln \mathrm{C}$ & $1.29(0.68)$ & - & $0.64(4.06)^{* * *}$ \\
$\ln \mathrm{H}$ & $3.94(2.58)^{* *}$ & $0.63(1.93)^{* *}$ & - \\
\hline & & & (continued)
\end{tabular}


IJMS 20 (1), 41-75 (2013)

\begin{tabular}{|c|c|c|c|}
\hline \multirow{2}{*}{ Explanatory variables } & \multicolumn{3}{|c|}{ Dependent variable } \\
\hline & $\ln K$ & $\ln L$ & $\ln \mathrm{H}$ \\
\hline \multicolumn{4}{|c|}{ Diagnosis tests } \\
\hline Serial correlation & $1.55\{0.24\}$ & $2.64\{0.12\}$ & $2.45\{0.14\}$ \\
\hline Functional form & $1.30\{0.28\}$ & $1.94\{0.18\}$ & $0.40\{0.54\}$ \\
\hline Normality & $0.18\{0.99\}$ & $0.54\{0.77\}$ & $1.4\{0.12\}$ \\
\hline Heterocedasticity & $1.05\{0.32\}$ & $0.08\{0.79\}$ & $0.78\{0.39\}$ \\
\hline CUSUM & Stable & Stable & Stable \\
\hline CUSUMSQ & Stable & Stable & Stable \\
\hline
\end{tabular}

Notes.

\# Serial correlation is F-statistics of Breusch-Godfrey serial correlation LM test. B: Functional form is F-statistics of Ramsey's RESET test using the square of the fitted values. Normality is LM - statistics of skewness and kurtosis of residuals for normality test. Heteroskedasticity is F-statistics of white Heteroskedasticity test. CUSUM; Cumulative Sum of Recursive Residuals is the stability test of the long-run coefficients together with the short-run dynamics based on Pesaran and Pesaran (1997). CUSUMSQ; Cumulative Sum of Squares of Recursive Residuals is the stability test of the long-run coefficients together with the short-run dynamics based on Pesaran and Pesaran (1997). \# $\mathrm{t}$-statistic in ( ) \& prob for F statistic in \{\} .

$\left.\#\left(^{* *}\right),{ }^{* *}\right)$ denotes significant at $1 \%$ and $5 \%$ level respectively.

In equation with the human capital as a dependent variable, it explains that in the long-run, all the selected variables (K, L and $\mathrm{Y}$ ) play a positive and significant role in the human capital accumulation of the country. The employment variable is the most important and has the highest significance regarding human capital, as indicated by the $t$ ratio. The elasticity of human capital with respect to employment is positive and equal to 0.64 , which means that, on average, an increase in employment by 1 per cent leads to an increase in the average years of schooling by 0.64 per cent. In fact, a high employment rate means that many people are employed. This could mean that companies are hiring and job opportunities are increasing, which induce people to improve their skills through education. Furthermore, another influential variable in determining human capital stock of a country is the accumulation of capital stock. The results suggest that, on average, an increase in the accumulation of capital stock by 1 per cent reflects a 0.14 per cent increase in the human capital of a country. These results indicate that an increase in the capital stock will lead to an increase in investment and new firms will emerge. The resulting increase in the demand for labour will influence people to build their capacity and improve their skills to meet this increasing demand for labour. Although economic growth negatively influences human capital accumulation, the effect is insignificant. 
When employment (L) is considered as an endogenous variable, the results suggest that, in the long-run, economic growth and human capital are the main determinants of the employment level of a country, as indicated by the $t$ ratio. On average, a 1 per cent increase in economic growth and human capital leads to an increase in employment by 0.31 per cent and 0.63 per cent respectively. Here, the change in the employment level is highly sensitive to any change in the stock of the human capital compared to the economic growth. The conclusion regarding the positive relationship between education and employment supports previous findings (Mclntosh, 2008).

Table 5 also suggests that in the long-run only human capital is the main determinant for the capital stock accumulation of a country, while the other variables play positive but insignificant roles. Human capital is an important factor in the capital stock accumulation process for two principal reasons. Firstly, any country characterized by a high level of human capital can attract foreign investment because higher educated people facilitate the adoption and design of new technology, thus reducing costs of production and increasing the profits (Hoffman, 2003; Noor Bakhsh \& Paloni, 2001). In Malaysia, foreign direct investment (FDI) as a percentage of GDP increased from 0.6 per cent in 2001 to 4.53 per cent in 2007 (World Bank), which confirms the hypothesis of the positive relationship between FDI and human capital. Secondly, education plays a significant role in the positive relationship between income, savings and investment. For example, schooling may enable people to appreciate the finer things in life or to be more efficient in making consumption decisions (see Solomon, 1975 who discusses a number of theories that might be helpful in predicting the relationship between education and savings behaviour). We can conclude that the non-monetary returns from education are relatively high for capital stocks (3.94 per cent) compared with employment ( 0.63 per cent). This indicates that expansion in education attracts more investment to the country.

The short-run relationship is estimated through Equation (8), and the results are presented in Table 6 . The table demonstrates that all equations have the same pattern of that of the long-run indicating that the explanatory variables have a similar impact in the shortrun as in the long-run. The only distinction is the insignificant influence of human capital on capital stock in the short-run. In fact, this observation is consistent with the return to investment in the education theory, which states that the return from education occurs in the long-run. However, if we look for the same return for 
employment, we find it is statistically significant, which means that the country enjoys a considerable return from education in the form of increased employment, even in the short-run.

Table 6

Short-run Relationship

\begin{tabular}{lccc}
\hline \multirow{2}{*}{$\begin{array}{c}\text { Explanatory } \\
\text { variables }\end{array}$} & \multicolumn{3}{c}{ Dependent variables } \\
\cline { 2 - 4 } Constant & $8.92(2.38)^{* *}$ & $0.39(0.44)$ & $-1.77(4.42)^{* * *}$ \\
$\mathrm{D} \ln \mathrm{Y}$ & $0.13(0.58)$ & $0.17(3.22)^{* * *}$ & $-1.07(0.14)$ \\
$\mathrm{D} \operatorname{lnK}$ & - & $-0.03(0.32)$ & $0.067(1.97)^{* *}$ \\
$\mathrm{D} \ln \mathrm{C}$ & $0.37(0.74)$ & - & $0.32(3.78)^{* * *}$ \\
$\mathrm{D} \ln \mathrm{H}$ & $0.61(0.78)$ & $0.72(2.48)^{* *}$ & - \\
$\mathrm{ECT}(-1)$ & $-0.39(1.94)^{* *}$ & $-0.53(4.14)^{* * *}$ & $-0.50(6.11)^{* * *}$ \\
& & Goodness of Fit & \\
$\mathrm{R}^{2}$ & $0.92 \quad 0.67$ & 0.78 \\
$\mathrm{R}^{-2}$ & 0.84 & 0.59 & 0.69 \\
F-stat & $12.60^{* * *}$ & $9.90^{* * *}$ & $12.32^{* * *}$ \\
\hline
\end{tabular}

Notes.

\# T-statistic value in ( ).

$\#\left({ }^{* * *}\right),\left({ }^{* *}\right)$ and $\left({ }^{*}\right)$ denotes significant at $1 \%, 5 \%$ and $10 \%$ level respectively.

The lagged error term $\left(\mathrm{ECT}_{(-1)}\right)$ in all forms of equations in the results is negative and significant at 1 per cent, 1 per cent and 5 per cent for equations where $\mathrm{K}, \mathrm{L}$, and $\mathrm{H}$ are considered as dependent variables respectively. In this case when $\mathrm{H}$ (schooling) is a dependent variable, the coefficient for a suitable rate of convergence towards potential long-run human capital accumulation is -0.50 . This means that the previous year of disequilibrium is corrected on average by about 50 per cent in the following year. Since the result for the ECT $\mathrm{T}_{(-1)}$ coefficient is significant, this provides an evidence of a causality in at least one direction.

Finally, the stability of the long-run coefficients is examined with the short-run dynamics based on Pesaran and Pesaran (1997), by applying the CUSUM and the CUSUMSQ proposed by Brown et al. (1975). The CUSUM tests basically use the cumulative sum of the recursive residuals based upon the first set of $n$ observations and are updated recursively and plotted against the break points. If the plot of CUSUM remains within the critical bounds at 5 per cent significance 
level (represented by clear and straight lines drawn at 5 per cent), the null hypothesis for all the coefficients and the error correction model are stable and cannot be rejected. However, if the two lines are crossed, the null hypothesis of coefficient stability cannot be rejected. The same analysis applies for the CUSUMSQ test, which is based upon the squared recursive residuals. The results of both tests in all equations suggest the stability of the long-and short-run coefficients as shown in Table 5. The table also demonstrates that all the equations have passed the selected diagnostic tests, viz., the serial correlation, model specification, normality and heteroskedasticity test.

\section{(c) Causality test}

As mentioned previously, the significance of the $\mathrm{ECM}_{(-1)}$ coefficient is that it is an evidence of causality in at least one direction. Moreover, it is necessary to remember that the existence of a cointegration relationship is a necessary condition, but not sufficient to demonstrate the existence of a causality relationship. In this respect, Granger (1980) noted that it is conceivable that two variables may be highly correlated, but not necessarily linked by causality.As opposed to the conventional Granger causality method, the errorcorrection-based causality test allows for the inclusion of the lagged error-correction term derived from the co-integration equation. By including the lagged error-correction term, the long-run information lost through differencing is reintroduced in a statistically acceptable way.

Through the $\mathrm{ECT}_{(-1)^{\prime}}$ in Equation (8) an error-correction model offers an alternative test of causality (or weak exogeneity) of the dependent variable. For example, if $\theta$ in Equation (8) is zero, then it can be implied that the change in $\mathrm{Y}$ does not respond to deviation in the long-run equilibrium in period $t-1$. Also, if $\theta$ equals zero and both, for example, $\Psi, \Omega$ and $\phi$ are zero, it can be implied that employment (dlnL), capital stock $(\mathrm{d} \operatorname{lnK})$ and human capital $(\mathrm{d} \ln \mathrm{H})$ do not Granger-cause Y. The non-significance of both the $t$ and Wald F-statistic in Equation (8) will imply that dependent variable is weakly exogenous. If the variables are co-integrated then it is expected that at least one or all of the ECTs, 1) should be significantly non-zero. Granger causality of the dependent variables is tested in this study as follows: (a) by a simple t-test of the $\theta$ in Equation 8 (b) by a joint Wald F-statistic of the significance of the sum of the lags of each of the explanatory variables in turn and (c) by joint Wald F-statistic of the interactive terms between $E C T_{(-1)}$ 
of the dependent variable with each explanatory variable separately. For example, suppose that dln $Y$ is a dependent variable in Equation (8) and $\theta$ represents its $\mathrm{ECT}_{(-1)}$ coefficient and it is significant. The joint Wald test suggests testing the coefficient for each independent variable separately against $\theta$. If the joint Wald F-statistic, for example, between $\Psi$ (capital stock coefficient) and $\theta$ is significant, this indicates that capital stock causes economic growth in the long run. Table 7 below depicts, the results of the result of the Wald test for the causality relationship.

Table 7

Wald Test

\begin{tabular}{|c|c|c|c|c|c|c|c|c|c|}
\hline \multirow{3}{*}{$\begin{array}{l}\text { Dependent } \\
\text { variable }\end{array}$} & \multicolumn{4}{|c|}{ Short-run causation } & \multicolumn{5}{|c|}{ Long-run causation } \\
\hline & $D \ln Y$ & DlnK & $D \ln L$ & $\mathrm{D} \ln \mathrm{H}$ & \multirow{2}{*}{$\begin{array}{l}\mathrm{ECT}_{-1} \\
\text { (t-stat) }\end{array}$} & $\begin{array}{l}\mathrm{D} \ln Y \\
\mathrm{ECT}\end{array}$ & $\begin{array}{l}\mathrm{D} \ln K \\
\mathrm{ECT}\end{array}$ & $\begin{array}{l}\text { DlnL } \\
\text { ECT }\end{array}$ & $\begin{array}{c}\text { DlnH } \\
\text { ECT }\end{array}$ \\
\hline & \multicolumn{4}{|c|}{ Short run causation } & & \multicolumn{4}{|c|}{ Long-run causation } \\
\hline DlnK & $\begin{array}{c}1.97 \\
(0.16)\end{array}$ & - & $\begin{array}{c}0.55 \\
(0.46)\end{array}$ & $\begin{array}{l}4.05^{* *} \\
(0.044)\end{array}$ & $\begin{array}{l}-0.39^{* * *} \\
\{0.052\}\end{array}$ & $\begin{array}{l}11.60^{* * * *} \\
(0.003)\end{array}$ & - & $\begin{array}{l}10.30^{* * * *} \\
(0.006)\end{array}$ & $\begin{array}{l}13.60^{* * * *} \\
(0.001)\end{array}$ \\
\hline DInL & $\begin{array}{l}6.12^{* * *} \\
(0.013)\end{array}$ & $\begin{array}{c}0.10 \\
(0.75)\end{array}$ & - & $\begin{array}{r}4.55^{* *} \\
(0.033)\end{array}$ & $\begin{array}{l}-0.53^{* * * *} \\
\{0.000\}\end{array}$ & $\begin{array}{l}8.08^{* * *} \\
(0.018)\end{array}$ & $\begin{array}{r}6.97^{* *} \\
(0.031)\end{array}$ & - & $\begin{array}{c}6.32^{\text {** }} \\
(0.042)\end{array}$ \\
\hline $\mathrm{DlnH}$ & $\begin{array}{c}3.48^{* *} \\
(0.062)\end{array}$ & $\begin{array}{l}6.65^{* * *} \\
(0.010)\end{array}$ & $\begin{array}{c}25.22^{* * * *} \\
(0.000)\end{array}$ & - & $\begin{array}{l}-0.50^{* * * *} \\
\{0.000\}\end{array}$ & $\begin{array}{c}32.67^{* * * *} \\
(0.000)\end{array}$ & $\begin{array}{l}35.11^{* * *} \\
(0.000)\end{array}$ & $\begin{array}{l}34.02^{* * * *} \\
(0.000)\end{array}$ & - \\
\hline
\end{tabular}

Notes.

\# $\mathrm{t}$-statistic in \{\}$\& \mathrm{~F}$ statistic in ().

$\#\left({ }^{* * *}\right)$ and $\left(^{* *}\right)$ denotes significant at $1 \%$ and $5 \%$ level respectively.

Based on F-statistic, Table 7 shows that in the short-run, the direction of the causality is from economic growth, capital stock and employment to human capital. In addition, the results also detected two way relationships between capital stock $(\mathrm{K})$ and human capital $(\mathrm{H})$, as well as between employment $(\mathrm{L})$ and human capital $(\mathrm{H})$ in the short run. The result implies that while the average level of the human capital of the country attracts the investment, the flow of investment will also positively affects investment in human development.

Since all explanatory variables for the human capital equation on the left hand side are significant and the $t$ value for ECT of the same equation is also significant, this implies that in case of a deviation of the human capital from the long-run equilibrium relationship, all the explanatory variables interact in a dynamic fashion to restore the long-run equilibrium, whilst the F-statistic on the right and side indicates the existence of two way long-run causality relationships 
between each two variables. The most interesting finding is that, the causality between economic growth, capital stock and employment with human capital appears to be in both, the short run and the long run as well.

\section{(d) Impulse response function}

In its simplest sense, an impulse response function outlines the effect of a one-time shock to one of the innovations on current and future values of the endogenous variables. Given that the innovations are contemporaneously uncorrelated, interpretation of the impulse response is simple: the $n$th innovation is simply a shock to the nth endogenous variable. In other words, an impulse response function is helpful in tracing the time path of the various shocks on the variables contained in the VAR system. Through the dynamic structure of VAR, a shock to a variable directly affects itself, and all of the endogenous variables. In this analysis, all responses are based upon a one-year lag interval.

The results presented in Figure (8) indicate the response of human capital stock $(\mathrm{H})$ to innovations that come from real capital stock (K) based on a one-year lag is positive to the fourth year; attaining its peak at the third year and declining gradually until reaching a minimum level in the seventh year; and then maintaining a stable flow in the long run. The response of human capital stock $(\mathrm{H})$ to innovations that comes from employment $(\mathrm{L})$ is positive for the first five years; negative from five years until eight years; and then maintains a stable flow in the long run. With a one-year lag, the dependent variable (LH) responded positively to the innovations of employment, which increased sharply within one to two years; gradually peaked at five years then declined gradually until reaching its minimum level in the eighth year; and then maintaining a stable flow in the long run. The response of human capital stock $(\mathrm{H})$ to innovations that come from economic growth $(\mathrm{Y})$ is completely positive. With a one-year lag, the dependent variable (LH) responded positively to the innovations of growth, which increased gradually until reaching its peak in the sixth year and then maintaining a stable flow in the long run. Clearly, if human capital stock in Malaysia witnesses any innovations from either capital stock, employment or economic growth, human capital stock can be predicted to return back to it is long-run equilibrium bath after 6 to 8 years. 


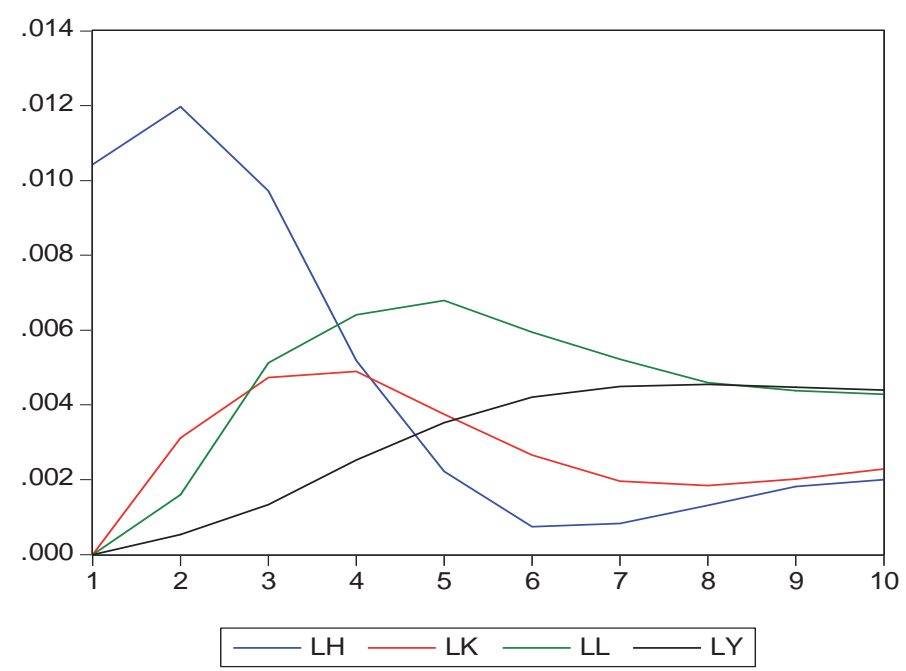

Figure 8. Response of LH to Cholesky One S.D. Innovations.

In Figure (9) the response of the real capital stock (K) to innovations that comes from human capital stock $(\mathrm{H})$ is based on one-year lag is fluctuations. The response is positive until the second year; declines in the third year; increases in the fourth year; declines sharply in the fifth year; decreases gradually until the seventh year; and then maintains its flow at a neutral level in the long-run. The response of the real capital stock $(\mathrm{K})$ to shocks that come from employment $(\mathrm{L})$ is similar to the response of human capital stock to shocks. The response is positive until the second year; declines sharply in the third year; increases in the fourth year; declines sharply in the fifth year; increases gradually until the sixth year; and then maintains its flow at a neutral level in the long run. The response of the real capital stock $(\mathrm{K})$ to shocks that comes from economic growth $(\mathrm{Y})$ is completely positive, responding positively until the second year; attaining its peak in the fourth year; and then maintaining its flow at a neutral level in the long run.

In Figure (10), the response of employment (L) to innovations that comes from human capital stock $(\mathrm{H})$ based on a one-year lag declines within the first two years; fluctuates until the fifth year; increases slightly until the seventh year; and then maintains its flow at a neutral 
level in the long run. Also the response of employment to any shocks from capital stock is negative within the first three years; increases slightly until peaking at nine years; and then maintains its flow at a neutral level in the long run. On the other hand, the response of employment to any shock from economic growth is positive for the first three years; declines slightly to attain its minimum in the sixth year; and then maintains its flow at a neutral level in the long run. We can conclude this section by arguing that in case of any shocks coming from the exogenous variables, based upon a one year lag, all of the endogenous variables will return to a long run equilibrium path within six to eight years.

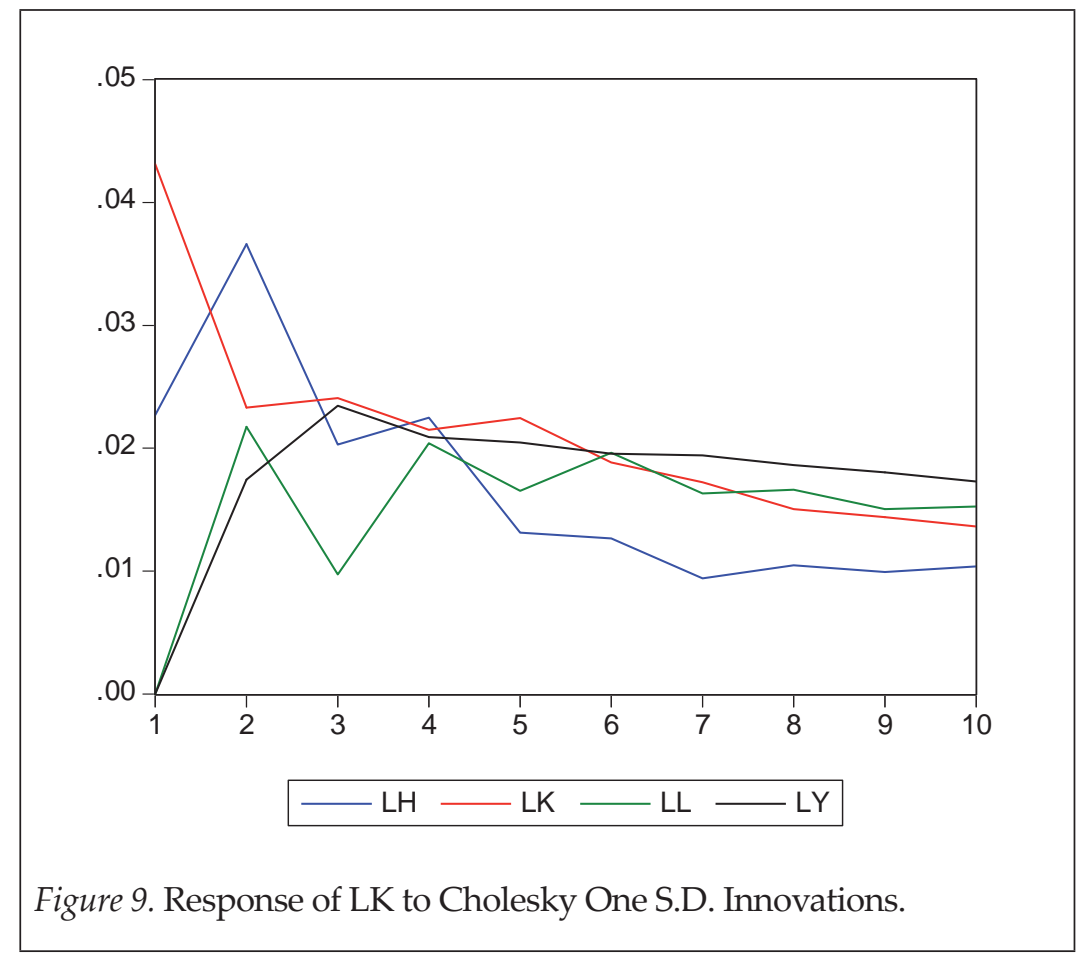

\section{(e) Variance decomposition}

With the VECM, F- and t-tests may be interpreted as within-sample causality tests and indicate only the Granger causality of the dependent variable within the sample period. The tests provide little evidence on the dynamic properties of the system, the relative strength of the Granger causal chain or the degree of exogeneity among the variables. On the other hand, the variance decompositions (VDCs), 
by partitioning the variance of the forecast error of a certain variable into the proportions attributable to innovations (or shocks) in each variable in the system including its own, can provide an indication of these relativities. VDCs may be termed as out-of-sample causality tests (Bessler \& Kling, 1985). The variable that is optimally forecast from its own lagged values will have all of its forecast error variance explained by its own disturbances (Sims, 1982).

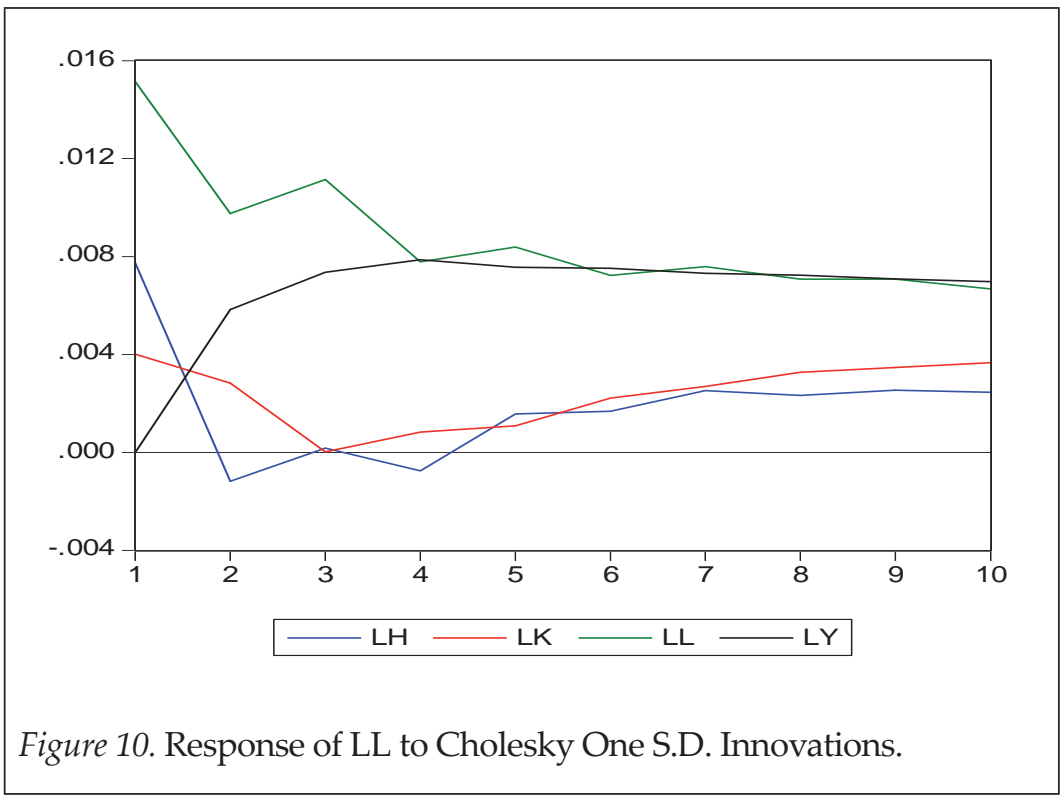

An examination of the short-run dynamic properties of economic growth is further supplemented by forecast error variance decomposition (FEVD), which provides complementary information on the dynamic behaviour of the variables in the system. The decomposition of the forecast variance into the contributions by each of the different shocks is possible. When calculated by structural shocks, as in the present case, the FEVD provides information on the importance of various structural shocks in explaining the forecast error variability of economic growth and its determinants.

The variance decomposition results for 10 periods can be seen on Tables $8-11$. Consistent with the findings from the co-integration results, the variance decomposition analysis revealed that the behaviour of real GDP (Y) is strongly exogenous, while human capital stock $(\mathrm{H})$, employment (L) and real capital stock (K) are strongly endogenous. 
IJMS 20 (1), 41-75 (2013)

Table 8

Variance Decomposition of $\ln H$

\begin{tabular}{cccccc}
\hline Period & S.E. & $\operatorname{lnH}$ & $\operatorname{lnK}$ & $\ln \mathrm{l}$ & $\operatorname{lnL}$ \\
\hline 1 & 0.011226 & 100.0000 & 0.000000 & 0.000000 & 0.000000 \\
2 & 0.014395 & 93.96099 & 1.276045 & 0.246217 & 4.516746 \\
3 & 0.016593 & 85.67176 & 2.027816 & 1.691513 & 10.60891 \\
4 & 0.018445 & 77.01188 & 2.255524 & 4.677379 & 16.05521 \\
5 & 0.020149 & 68.77489 & 2.228769 & 8.906838 & 20.08951 \\
6 & 0.021775 & 61.35087 & 2.110113 & 13.87527 & 22.66375 \\
7 & 0.023345 & 54.87355 & 1.973197 & 19.12940 & 24.02385 \\
8 & 0.024865 & 49.32238 & 1.847176 & 24.34675 & 24.48370 \\
9 & 0.026333 & 44.60341 & 1.741886 & 29.32827 & 24.32643 \\
10 & 0.027749 & 40.59977 & 1.659218 & 33.96650 & 23.77452 \\
\hline
\end{tabular}

As shown in Table 8, the variation of the human capital stock ranged from 40 per cent to 100 per cent over a ten year horizon. The innovations of real capital stock $(\mathrm{K})$, economic growth $(\mathrm{Y})$ and employment $(\mathrm{L})$ account for the forecast error variance of human capital $(\mathrm{H})$, ranging from 0 to 0.16 per cent, 0 to 33.97 per cent and 0 to 23.78 per cent respectively. The persistence of human capital after the tenth quarter period of shocks explains 40 per cent of the variance of human capital, while capital stock, economic growth and employment account for 60 per cent.

Table 9

Variance Decomposition of $\ln K$

\begin{tabular}{cccccc}
\hline Period & S.E. & $\ln \mathrm{H}$ & $\ln \mathrm{ln} Y$ & $\ln \mathrm{Y}$ \\
\hline 1 & 0.052987 & 14.12061 & 85.87939 & 0.000000 & 0.000000 \\
2 & 0.063925 & 19.25333 & 75.93788 & 4.791758 & 0.017037 \\
3 & 0.071404 & 21.29857 & 66.27358 & 12.37008 & 0.057774 \\
4 & 0.078016 & 21.34369 & 57.85510 & 20.49568 & 0.305533 \\
5 & 0.084333 & 20.37445 & 50.74779 & 28.14674 & 0.731010 \\
6 & 0.090488 & 18.99965 & 44.82686 & 34.95450 & 1.218988 \\
7 & 0.096491 & 17.54252 & 39.92589 & 40.85583 & 1.675765 \\
8 & 0.102318 & 16.15529 & 35.87565 & 45.91577 & 2.053295 \\
9 & 0.107942 & 14.89833 & 32.52163 & 50.24166 & 2.338382 \\
10 & 0.113345 & 13.78650 & 29.73154 & 53.94491 & 2.537053 \\
\hline
\end{tabular}

In Table 9, when capital stock (K) is decomposed into economic growth, human capital stock, capital stock and employment, the variance error decomposition varies. The persistence of capital stock 
shocks after the tenth quarter period of the shocks explains 29 per cent of the variance of capital stock, while others account for 71 per cent.

Table 10

Variance Decomposition of $\ln Y$

\begin{tabular}{cccccc}
\hline Period & S.E. & $\ln H$ & $\ln K$ & $\ln Y$ & $\ln L$ \\
\hline 1 & 0.037570 & 1.979071 & 24.34448 & 73.67645 & 0.000000 \\
2 & 0.053012 & 2.232852 & 17.50171 & 80.25097 & 0.014464 \\
3 & 0.064792 & 2.262807 & 13.86715 & 83.85993 & 0.010120 \\
4 & 0.074563 & 2.206803 & 11.68044 & 86.09978 & 0.012976 \\
5 & 0.082996 & 2.122768 & 10.23295 & 87.61525 & 0.029031 \\
6 & 0.090452 & 2.034121 & 9.205891 & 88.70537 & 0.054622 \\
7 & 0.097151 & 1.949968 & 8.439587 & 89.52565 & 0.084796 \\
8 & 0.103238 & 1.873437 & 7.846344 & 90.16439 & 0.115832 \\
9 & 0.108815 & 1.805154 & 7.374137 & 90.67524 & 0.145471 \\
10 & 0.113957 & 1.744733 & 6.990085 & 91.09263 & 0.172556 \\
\hline
\end{tabular}

By definition, the variance decomposition shows the proportion of forecast error variance for each variable that is attributable to its own innovation and to innovation in the other endogenous variables. In Table 10, "own shocks" constitute the predominant source of variation in economic growth forecast errors. The variation ranged from 73 per cent to 91 per cent over the ten-year horizon. The persistence of economic growth shocks after the tenth quarter period of the shocks explains 73 per cent of the variance of economic growth, while employment, human capital and capital stock, account for 0.17 per cent, 1.74 per cent, and 6.99 per cent respectively.

Table 11

Variance Decomposition of $\ln L$

\begin{tabular}{cccccc}
\hline Period & S.E. & $\operatorname{lnH}$ & $\operatorname{lnK}$ & $\ln \mathrm{Y}$ & $\operatorname{lnL}$ \\
\hline 1 & 0.019294 & 4.234582 & 0.005325 & 12.77126 & 82.98883 \\
2 & 0.026294 & 4.251099 & 0.089092 & 18.69239 & 76.96742 \\
3 & 0.031282 & 4.125181 & 0.108636 & 24.39171 & 71.37447 \\
4 & 0.035280 & 3.947275 & 0.095149 & 29.78300 & 66.17458 \\
5 & 0.038687 & 3.756463 & 0.079143 & 34.80980 & 61.35460 \\
6 & 0.041700 & 3.569649 & 0.075388 & 39.43509 & 56.91988 \\
7 & 0.044433 & 3.393992 & 0.088577 & 43.64276 & 52.87467 \\
8 & 0.046953 & 3.232201 & 0.118350 & 47.43596 & 49.21349 \\
9 & 0.049301 & 3.084877 & 0.162176 & 50.83261 & 45.92034 \\
10 & 0.051505 & 2.951602 & 0.216840 & 53.86027 & 42.97129 \\
\hline
\end{tabular}


In Table 11, the variation of employment ranged from 42 per cent to 82 per cent across the ten-year horizon. The innovations of real capital stock $(\mathrm{K})$, economic growth $(\mathrm{Y})$ and human capital $(\mathrm{H})$-ranging from 0.005 per cent to 0.21 per cent, 12.77 per cent to 53.86 per cent and 4.23 per cent to 2.95 per cent respectively -account for the forecast error variance of employment (L). The persistence of employment after the tenth quarter of shocks explains 42 per cent of the variance of employment, while capital stock, economic growth and employment account for 58 per cent.

\section{Conclusion}

The paper examined the long-run and short-run relationship between education and economic growth in Malaysia between 1970 and 2009. The empirical analysis was carried out utilising the ARDL framework, as well as a Grangers causality test. The objective of the study was to test the impact of human capital on economic growth. The results reveal that the co-integration relationship is non-existent when economic growth is labelled as a dependent variable, but exists otherwise. This implies that in the case of the Malaysian economy, economic growth is absolutely exogenous and the remaining variables are endogenous. The finding suggests that economic growth experienced by Malaysia's economy in the last few decades has helped to finance and further expand human capital accumulation within the country. This is achievable through vast investment allocated to national education and the training system as reflected by its previous five year economic plans.

The most interesting results are that the long-run forcing variables for human capital stock are capital stock, employment and economic growth. However, the causality test revealed that in the short-run there is a two-way relationship between human capital and employment, as well as a one-way relationship running from economic growth to employment; and from capital stock to economic growth. Thus, Malaysia should continue to invest in human capital enhancement since this could facilitate the employability of the workforce, as well an encourage more investment into the country. However, these results should be interpreted with caution since they may be affected when using a relatively larger data set. Future studies may expand upon this research by integrating policy variables and determining the effects upon the economy. 


\section{End Notes}

$1 \quad$ For more information about methodology used by Barro and Lee (2010) to calculate this indicator visit the authors' website (www.barolee.com).

2 See, for example, Davidson and MacKinnon (1993), Chapter 20, Hamilton (1994a), Chapter 17; and Hayashi (2000) Chapter 9.

\section{References}

Abbas, Q., \& Peck, J. F. (2008). Human capital and economic growth: Pakistan, 1960-2003. The Lahore Journal of Economics, 13(1), 1-27. Abbas, T. (2001). How South Asians achieve in education (Unpublished doctoral thesis). Warwick: University of Warwick.

Abu-Qarn, A., \& Abu-Bader, S. (2007). Sources of growth revisited: Evidence from selected MENA countries. World Development, 35(5), 752-71.

Adawo, M. A. (2011). Has education (human capital) contributed to the economic growth of Nigeria. Journal of Economics and International Finance, 3(1), 46-58.

Ahmad Fauzi Puasa, Zakariah Abdul Rashid, \& Raja Zarina Raja Mohamad. (2011). The economic impact of the Economic Transformation Plan (ETP) on Malaysian economy by the year 2020: An input-output analysis. International Journal of Management Studies, 18(2), 101-120.

Asteriou, D., \& Agiomirgianakis, G. M. (2001). Human capital and economic growth: Time series evidence from Greece. Journal of Policy Modelling, 23, 481-89.

Barro, R., \& Lee, J. W. (2010). International data on educational attainment: Updatesand implications. Department of Economics, Harvard University. Retrieved from http://www.cid.harvard. edu/ciddata

Barro, R. J., \& Lee, J. W. (1993). International comparisons of educational attainment. Journal of Monetary Economics, 32(3), 363-394.

Barro, R. J. (1991). Economic growth in a cross-section of countries. Quarterly Journal of Economics, 6(2), 407-443.

Barro, R. J. (2001). Human capital and growth. American Economic Review, 91(2), 12-17.

Barro, R. J., \& Lee, W. (2001). Schooling quality in a cross-section of countries, Economica, 68(272), 465-488.

Benhabib, J., \& Spiegel, M. (1994). The role of human capital in economic development: Evidence from aggregate crosscountry data. Journal of Monetary Economics, 34, 143-174. 
Bessler, D., \& Kling, J. (1985). A note on tests of Granger causality. Applied Econometrics, 16, 335-342.

Bisat, A., El Erian, M., \& Helbling, T. (1997). Growth, investment and savings in the Arab Economies. IMF Working Paper WP/97/85. Washington, DC: IMF.

Brown, R. L., Durbin, J., \& Evans, J. M. (1975). Techniques for testing the constancy of regression relations over time. Journal of the Royal Statistical Society, 37(B), 149-163.

Caselli, F., Esquivel, G., \& Lefort, F. (1996). Reopening the convergence debate: A new look at cross-country growth empirics. Journal of Economic Growth, 1, 363-389.

Choong, C., Zulkornain, Y., \& Venus, L. (2005). Export led growth hypothesis in Malaysia: An investigation using bounds test. Sunway Academic Journal, 2, 13-22.

Dahlin, B. G. (2005). The impact of education on economic growth: Theory, findings and policy implications. Working Paper. Duke University, North Carolina.

De Meulemeester, J. L., \& Rochat, D. (1995). A causality analysis of the link between higher education and development. Economics of Education Review, 14, 351-361.

DeJong, D. N., Nankervis, J. C., Savin, N. E., \& Whiteman, C. H. (1992). The power problems of unit root tests for time series with autoregressive errors. Journal of Econometrics, 53, 323-343.

Denison, E. F. (1962). Sources of economic growth in the United States and the alternatives before us. Supplement Paper 13. Committee for Economic Development, New York.

Denison, E. F. (1967). Why growth rates differ. Washington, DC: The Brookings Institute.

Granger, C. W. J. (1980).Testing for causality: A personal viewpoint. Journal of Economic Dynamics and Control, 2, 329-352.

Gyimah-Brempong, K., Paddison, O., \& Mitiku, W. (2006). Higher education and economic growth in Africa. Journal of Development Studies, 42(3), 509-529.

Hanushek, E. A., \& Kimko, D. (2000). Schooling, labour force quality, and the growth of nations. American Economic Review, 90(5),1184-1208.

Heckman, J. J., \& Klenow, P. J. (1997). Human capital policy. Mimeo, Chicago: University of Chicago.

Hoffman, A. N. (2003). Education, trade and investment liberalizations. Journal of International Economics, 60(2), 433-453.

Hui-Boon Tan, Mei-Foong Wong, \& Zaleha Mohd Noor. (2006). Education and growth in Malaysia knowledge-based economy. International Journal of Economics and Management, 1(1), 141-154. 
Idris Jajri \& Rahmah Ismail. (2010). Impact of labour quality on labour productivity and economic growth. African Journal of Business Management, 4(4), 486-495.

International Labour Organization. (1982). The Thirteenth International Conference of Labour Statisticians. Geneva: ILO.

Ishak Yussof, \& Zainizam Zakariya. (2009). Pertumbuhan ekonomi dan keperluan pendidikan tinggi Malaysia. Jurnal Ekonomi Malaysia, 43, 85-105.

Islam, N. (1995). Growth empirics: A panel data approach. Quarterly Journal of Economics, 110, 1127-1170.

Johansen, S., \& Juselius, K. (1990). Maximum likelihood estimation and inference on cointegration with application to the demand for money. Oxford Bulletin of Economics and Statistics, 52(2), 169-210.

Johnes, G. (2006). Education and economic growth. [Working paper]. Retrieved from http://ssrn.com

Jones, P. W. (1992). World Bank financing of education: Lending, learning, and development. New York: Routledge.

Jorgenson, D. W., Stiroh, K. J., Gordon, R. J., \& Sichel, D. E. (2000). Raising the speed limit:U.S. economic growth in the information age. Brookings Papers on Economic Activity, 1, 125-235.

Krueger, A. B., \& Lindahl, M. (2001). Education for growth: Why and for whom? Journal of Economic Literature, 39, 1101-1136.

Kwiatkowski, D., Phillips, P. C. B., Schmidt, P., \& Shin, Y. (1992). Testing the null hypothesis of stationarity against the alternative of a unit root. Journal of Econometrics, 54,159-178.

Lau, L. J., Jamison, D. T., \& Lou, F. F. (1991). Education and productivity in developing countries: An aggregate production function approach. Policy Research Working Papers, 612. Washington, DC: The World Bank.

Lucas, R. E. (1988). On the mechanics of economic development. Journal of Monetary Economics, 22, 3-42.

Maddala, G. S., \& Kim, I-M. (1998). Unit roots, cointegration and structural change. Cambridge: Cambridge University Press.

Malaysia. (2010). 10th Malaysia Plan. Putrajaya: Government Printer.

McIntosh, C. N. (2008). Factor analysis of selected modules from the Canadian survey of experiences with primary health care (CSE-PHC). Health Information and Research Division Working Paper Series. Ottawa: Statistics Canada.

Mincer, J. (1974). Schooling, experience and earnings. New York: National Bureau of Economic Research.

Ndiyo, N. A. (2002). The paradox of education and economic growth in Nigeria: Empirical evidence. NES Proceedings. Nigerian Economic Society. 
Noor Bakhsh, F., \& Paloni, A. (2001). Human capital and FDI inflows to developing countries: New empirical evidence. World Development, 29(9), 1593-1610.

Ouattara, B. (2004). Foreign aid and fiscal policy in Senegal. Mimeo. Manchester: University of Manchester.

OECD. (1997). Thestate in a changing world. The World Development Report 1997. Paris: Organisation for Economic Co-operation and Development.

Papageorgiou, C. (2003). Distinguishing between the effects of primary and post primary education on economic growth. Review of Development Economics, 7(1),1-22.

Pesaran, M. H., \& Pesaran, B. (1997).Working with Microfit 4.0: Interactive econometric analysis. Oxford: Oxford University Press.

Pesaran, M. H., \& Shin, Y. (1999). An autoregressive distributed lagmodelling approach to co-integration analysis. In S. Strom (Ed.), Econometrics and economic theory in the 20th century: The Ragnar Frisch centennial symposium. Cambridge: Cambridge University Press.

Pesaran, M. H. (2001). Bounds testing approaches to the analysis of level relationships. Journal of Applied Econometrics, 16, 289-326.

Petrakis, P., \& Stamatakis, D. (2002). Growth and educational levels: A competitive analysis. Economics of Education Review, 21, 513-521.

Pritchett, L. (2001). Where has all the education gone? World Bank Economic Review, 15, 367-391.

Psacharopoulos, G. (1973). Returns to education: An international comparison. Amsterdam: Elsevier.

Psacharopoulos, G. (1984). The contribution of education to economic growth: International comparisons. In J. W. Kendrick (Ed.), International comparisons of productivity and causes of the slowdown (pp. 335-355). Ballinger: American Enterprise Institute.

Psacharopoulos, G. (1985). Returns to education: A further international update and implications. Journal of Human Resources, 20(4),583-604.

Psacharopoulos, G. (1989). Time trends of the returns to education: Cross national evidence. Economics of Education Review, 18(3), 225-231.

Psacharopoulos, G. (1994). Returns to investment in education: A global update. World Development, 22(9), 1325-1343.

Psacharopoulos, G. (1996). A reply to Bennell. World Development, 24(1), 201.

Psacharopoulos, G., Velez, E., Panagides, A., \& Yang, H. (1996). The returns to education during boom and recession: Mexico 1984, 1989 and 1992. Education Economics, 4(3), 219-230. 
Psacharopoulos, G. (1981). Education and the structure of earnings in Portugal. DeEconomist, 129(4), 532-545.

Rao, R. R., \& Rohana Jani. (2009). Spurring economic growth through education: The Malaysian approach educational. Research and Review, 4(4), 135-140.

Romer, P. (1986). Increasing returns and long-run growth. Journal of Political Economy, 5, 1002-1037.

Sari, R., \& Soytas, U. (2006). Income and education in Turkey: A multivariate analysis. Education Economics, 14, 181-196.

Schultz, T. W. (1960). Capital formation by education. Journal of Political Economy, 68, 571-583.

Schultz, T. W. (1961). Investment in human capital. American Economic Review, 51, 1-17.

Self, S., \& Grabowski, R. (2003).Education and long-run development. Japanese Journal of Asian Economics, 14(4), 565-580.

Self, S., \& Grabowski, R. (2004). Does education at all levels cause growth? India, a case study. Economics of Education Review, 23, 47-55.

Sims, C. A. (1982). Policy analysis with econometric models. Brookings Papers on Economic Activity, 1, 1367-1393.

Solomon, L. C. (1975). The relation between schooling and savings behaviour: An example of the indirect effects of education. In F. Thomas Juster (Ed.), Education, income, and human behavior (pp. 253-293). New York: McGraw-Hill.

Solow, R. M. (1957). Technical change and the aggregate production function. Review of Economics and Statistics, 39(3), 312-320.

Soto, M. (2002). Rediscovering education in growth regressions. OECD Development Centre Working Paper, No. 202. Paris York: OECD.

Teichler, U. (2000). Market forces in education. European Journal of Education, 35, 141-156.

Temple, J. (2001).Generalisations that aren't? Evidence on education and growth. European Economic Review, 45, 905-918.

UNESCO. (2008). Medium-term strategy for 2008-2013. Paris: United Nations Educational, Scientific and Cultural Organization.

Uwatt, B. (2002). Human development and economic growth in Nigeria (1960-2000). Selected papers for the 2002 Annual Conference of the Nigeria Economic Society (NES). Ibadan. Polygraphics Ventures.

World Bank. (1996). Bolivia: poverty, equity and income.World Bank Report No. 15272-BO. Washington, DC: World Bank.

World Bank. (2007). World Development Report 2008: Agriculture for development. Washington, D.C.: World Bank.

World Bank. (1994). Higher education: The lessons of experience. Washington, DC.: The World Bank. 
